\title{
Spores of many common airborne fungi reveal no ice nucleation activity in oil immersion freezing experiments
}

\author{
B. G. Pummer ${ }^{1,5}$, L. Atanasova ${ }^{2}$, H. Bauer ${ }^{3, \dagger}$, J. Bernardi ${ }^{4}$, I. S. Druzhinina ${ }^{2}$, J. Fröhlich-Nowoisky ${ }^{5}$, and H. Grothe ${ }^{1}$ \\ ${ }^{1}$ Institute of Materials Chemistry, Vienna University of Technology, Austria \\ ${ }^{2}$ Research Area Biotechnology and Microbiology, Institute of Chemical Engineering, \\ Vienna University of Technology, Austria \\ ${ }^{3}$ Institute of Chemical Technologies and Analytics, Vienna University of Technology, Austria \\ ${ }^{4}$ Service Center for Transmission Electron Microscopy, Vienna University of Technology, Austria \\ ${ }^{5}$ Department of Multiphase Chemistry, Max Planck Institute for Chemistry, Mainz, Germany \\ $\dagger$ deceased: 31 October 2012
}

Correspondence to: B. G. Pummer (b.pummer@mpic.de) and H. Grothe (grothe@tuwien.ac.at)

Received: 18 April 2013 - Published in Biogeosciences Discuss.: 20 June 2013

Revised: 6 November 2013 - Accepted: 13 November 2013 - Published: 10 December 2013

\begin{abstract}
Fungal spores are ubiquitous biological aerosols, which are considered to act as ice nuclei. In this study the ice nucleation (IN) activity of spores harvested from 29 fungal strains belonging to 21 different species was tested in the immersion freezing mode by microscopic observation of waterin-oil emulsions. Spores of 8 of these strains were also investigated in a microdroplet freezing array instrument. The focus was laid on species of economical, ecological or sanitary significance. Besides common molds (Ascomycota), some representatives of the widespread group of mushrooms (Basidiomycota) were also investigated.

Fusarium avenaceum was the only sample showing IN activity at relatively high temperatures (about $264 \mathrm{~K}$ ), while the other investigated fungal spores showed no freezing above $248 \mathrm{~K}$. Many of the samples indeed froze at homogeneous ice nucleation temperatures (about $237 \mathrm{~K}$ ). In combination with other studies, this suggests that only a limited number of species may act as atmospheric ice nuclei. This would be analogous to what is already known for the bacterial ice nuclei.

Apart from that, we selected a set of fungal strains from different sites and exposed them to occasional freezing stress during their cultivation. This was in order to test if the exposure to a cold environment encourages the expression of ice nuclei during growth as a way of adaptation. Although the total protein expression was altered by this treatment, it had no significant impact on the IN activity.
\end{abstract}

\section{Introduction}

Ice nucleation (IN) induced by primary biological aerosol particles, which include pollen, bacteria, and spores of fungi, is a current topic of intense debate. Several bacterial species (Pseudomonas syringae, Pseudomonas putida, Erwinia herbicola) were already found to catalyse ice formation at temperatures as warm as about $271 \mathrm{~K}$, which is much higher than for most organic or inorganic substances (e.g. GurianSherman and Lindow, 1993; Morris et al., 2004; Vali et al., 1976; Warren and Wolber, 1991). Microorganisms, which inhabit plant surfaces, are able to initiate the ice formation and cause frost injury to frost-sensitive plants (Gurian-Sherman and Lindow, 1993) - what resolves in a negative impact on agricultural crops. However, ice nuclei are useful in ice nucleation-limited processes such as artificial snow production, the freezing of some food products, and possibly in future weather modification schemes (Gurian-Sherman and Lindow, 1993).

Since fungal cells are present in the atmosphere in relevant numbers (Bauer et al., 2002), their impact on clouds is of interest. In the past, several researchers studied fungal ice nucleation and found high potential ice nuclei in some lichen mycobionts (Kieft, 1988; Kieft and Ahmadjian, 1989; Kieft and Ruscetti, 1990) and some species of the plant pathogenic fungal genus Fusarium (Pouleur et al., 1992; Hasegawa et al., 1994; Tsumuki and Konno, 1994; Tsumuki et al., 1995). It was proposed that these ice nuclei are proteins, but have 
little in common with the well-known bacterial ice nucleation proteins (Kawahara, 2002). For example, they are considered to be purely proteinaceous, while the bacterial ice nuclei are lipoglycoprotein complexes. Furthermore, they are more tolerant towards heat and acid treatment. Finally, they are not anchored in the wall, but can be easily washed off (Kieft and Ruscetti, 1990; Hasegawa et al., 1994; Tsumuki and Konno, 1994). Jayaweera and Flanagan (1982) found appreciable IN activity in Penicillium digitatum and Cladosporium herbarum. Only very recently, ice nuclei were found in other fungal species, like Isaria farinosa and Acremonium implicatum (Huffman et al., 2013), as well as in some rust and smut fungi (Morris et al., 2013; Haga et al., 2013). First tests showed that they strongly differ from the bacterial and Fusarium ones. For example, the rust fungi show properties of polysaccharide compounds (Morris et al., 2013). On the other hand, several representatives of Cladosporium showed only very poor IN activity in a former study by Iannone et al. (2011).

Although other work groups already investigated many different fungal species, some common Ascomycota, which are of economical, ecological or sanitary importance, and certainly available in the planetary boundary layer, were not studied before. Among those are many typical molds, belonging to the Aspergillus, Penicillium, and Trichoderma genus. The Basidiomycota were even less investigated, although their average atmospheric abundance might be higher than that of the Ascomycota (Pashley et al., 2012). Although there are some data about rust and smut fungi (Morris et al., 2013; Haga et al., 2013), no research has been done before on the largest group by far, namely the Agaricomycetes class, to which most of the edible mushrooms belong. According to recent studies, about $56 \%$ of the species present among the fungal spores in the atmosphere are Agaricomycetes (Fröhlich-Nowoisky et al., 2009).

At last, the atmospheric concentration of fungal ice nuclei is still debated, since data from atmospheric measurements are scarce. On the one hand, they seem to appear in far lower numbers than bacteria or mineral dust particles (Hoose et al., 2010; Sesartic et al., 2013). According to current climate models, the global impact of fungal spores is negligible. On the other hand, local events, for example rainfall in a forest area, can boost biological ice nuclei concentrations to significant levels (Huffman et al., 2013). Furthermore, the models consider only whole fungal spores and therefore do not include the impact of fragments, extracellular fluids and released constituent molecules. Therefore, estimations of the atmospheric impact of fungal spores are difficult to make, so it is still an open question whether spores of fungi contribute to atmospheric ice nucleation, if they carry a huge potential that simply has not been detected up to now in scientific studies.

In this study we measured a broad spectrum of fungal spores in a cryo-microscopic device, as it was used in the pollen study by Pummer et al. (2012), in order to close the most obvious gap and to gain greater knowledge of some important species, which have not been studied up to now, as well as Fusarium avenaceum, of which the IN activity is already known.

\section{Materials and methods}

\subsection{Species, cultivation and sampling design}

We chose the set of samples depending on four criteria: (1) species which had not been analysed concerning their IN activity before, (2) two well-studied Fusarium species in order to be able to compare our results with other published studies, (3) species which are abundant in the atmosphere, such as Agaricomycetes (Fröhlich-Nowoisky et al., 2009; Pashley et al., 2012), Cladosporium (Schüller, 2008; Ariya et al., 2009) and typical food molds (Aspergillus and Penicillium), and (4) species that have been found beyond the tropopause, like $E n$ gyodontium album, A. niger and $P$. chrysogenum (Imshenetsky et al., 1978; Pearce et al., 2009). Strains used in this study and their origin are presented in Table 1.

The spores of the Basidiomycota, namely Agaricus bisporus albidus (white button mushroom), Agaricus bisporus aveallaneous (cream button mushroom), Lentinula edodes (shiitake), Pleurotus ostreatus (oyster mushroom) and Psilocybe cubensis (magic mushroom) were purchased from the Mushroom Research Centre of Austria in the form of spore prints. Therefore, the caps of freshly harvested mushrooms were placed on an aluminium foil, which collected the spores crumbling out. To release the spores from the foil, we had to scratch them off gently with a sterilized metal speedle.

Furthermore, cultures of A. fumigatus, A. niger, A. oryzae, C. cladosporioides, $C$. herbarum, E. album, $F$. avenaceum, F. oxysporum, $P$. chrysogenum, $P$. digitatum, $P$. glabrum, $T$. atroviride, $T$. virens, $T$. longibrachiatum and $T$. reesei were obtained from the University of Natural Resources and Life Sciences in Vienna (Austria) and the TU Collection of Industrial Microorganisms (TUCIM; Vienna University of Technology, Vienna, Austria). Additionally, we sampled A. niger, $P$. chrysogenum and P. citrinum spores from decomposed food products (bread, carrot, lemon). The glycerine cultures of these strains are stored at $193 \mathrm{~K}$ in the TUCIM.

The obtained strains were cultivated on plates with different nutrient media in order to determine the optimum growth conditions. We applied malt extract agar (Sifin), potato dextrose agar (Sifin and Difco), synthetic nutrient-poor agar (Nirenberg, 1979) and overboiled rice (Pathre and Mirocha, 1978 ) as nutrient media. We achieved the greatest success in sample augmentation by cultivation on $3 \%$ potato dextrose agar (PDA, Difco) and incubation for seven days at $298 \mathrm{~K}$ in $12 \mathrm{~h}$ illumination cycles. Spores were then harvested using two different approaches. First we removed the fungal spores by gently beating a turned-around plate and collected them on a sterile Petri dish cover. The advantage of this method is 
Table 1. Origin and properties of studied Ascomycota.

\begin{tabular}{|c|c|c|c|c|}
\hline Species & Strain No. & Origin & Source of isolation & Date \\
\hline Fusarium avenaceum & MA 1220 & Vienna, Austria & paprika rhizoplane & $11 / 97$ \\
\hline F. oxysporum & $\begin{array}{l}\text { MA } 1085 \\
\text { TUCIM } 4301\end{array}$ & Eichkogel, Austria & - & - \\
\hline F. sp. & $\begin{array}{l}\text { TUCIM } 4237 \\
\text { TUCIM } 4682 \\
\text { TUCIM } 4686\end{array}$ & $\begin{array}{l}\text { Austria } \\
- \\
-\end{array}$ & $\begin{array}{l}- \\
\text { rye } \\
\text { rye }\end{array}$ & \\
\hline Aspergillus oryzae & MA 71 & - & - & $08 / 93$ \\
\hline A. fumigatus & MA 753 & Serengeti, Tanzania & lodge & $04 / 97$ \\
\hline A. niger & $\begin{array}{l}\text { MA } 1239 \\
-\end{array}$ & $\begin{array}{l}\text { Gloggnitz, Austria } \\
\text { Vienna, Austria }\end{array}$ & $\begin{array}{l}\text { marzipan praline } \\
\text { bread }\end{array}$ & $\begin{array}{l}01 / 98 \\
09 / 11\end{array}$ \\
\hline Penicillium chrysogenum & $\begin{array}{l}\text { MA } 265 \\
-\end{array}$ & $\begin{array}{l}\text { - } \\
\text { Vienna, Austria }\end{array}$ & $\begin{array}{l}- \\
\text { bread }\end{array}$ & $\begin{array}{l}11 / 94 \\
09 / 11\end{array}$ \\
\hline P. citrinum & - & Vienna, Austria & lemon & $03 / 12$ \\
\hline P. digitatum & MA 602 & Vienna, Austria & - & - \\
\hline P. glabrum & TUCIM 3351 & - & - & - \\
\hline Trichoderma atroviride & $\begin{array}{l}\text { TUCIM } 626 \\
\text { TUCIM } 1680 \\
\text { TUCIM } 1836 \\
\text { TUCIM } 3001\end{array}$ & $\begin{array}{l}\text { South America } \\
\text { Slovenia } \\
\text { Ethiopia } \\
\text { Israel }\end{array}$ & $\begin{array}{l}\text { seashore soil } \\
\text { mountain soil } \\
\text { soil } \\
\text { marine }\end{array}$ & $\begin{array}{l}- \\
- \\
-\end{array}$ \\
\hline T. longibrachiatum & TUCIM 1301 & Antarctica & - & - \\
\hline T. reesei & TUCIM 917 & Solomon Islands & cotton duck shelter & - \\
\hline T. virens & TUCIM 2550 & Ivory Coast & rainforest & - \\
\hline Cladosporium cladosporioides & $\begin{array}{l}\text { MA } 890 \\
\text { TUCIM } 4298\end{array}$ & Zwentendorf, Austria & gypsum & - \\
\hline C. herbarum & MA 1065 & Vienna, Austria & - & - \\
\hline Engyodontium album & MA 2848 & Johannessteinbruch, Austria & limestone & - \\
\hline
\end{tabular}

that the sample was not in contact with any equipment except for the collecting dish, so the risk of contamination is negligible. However, the efficiency of this technique is rather low and inappropriate for species which produce fewer or tighter bound spores. In the second approach about $10 \mathrm{~mL}$ ethanol was poured on the culture. The spores were then scratched off with a Drigalski spatula, and the suspension was filtered through glass wool, to separate the spores from the mycelia. The sustained spore suspension was then centrifuged, the supernatant was decanted, and finally the spore pellet was air dried. The surface morphology of the harvested spores was additionally investigated by scanning electron microscopy with a FEI Quanta $^{\mathrm{TM}} 200$ FEGSEM (see Fig. 1).

To investigate the effect of occasional freezing, a set of fungal strains (Table 2) was cultivated on four plates each: two of the plates were grown as usual at $298 \mathrm{~K}$, while the two others were exposed to occasional freezing events during their cultivation, meaning that they were left in the freezer for $12 \mathrm{~h}$. Then one plate of both procedures was harvested. The acquired spores were then tested for their IN activity. The other two plates were used for protein quantification (see Sect. 2.3).

\subsection{Ice nucleation in oil immersion}

We applied a cryo-microscopic setup, as described in Pummer et al. (2012), to determine the IN activity of the spores. Therefore a water-in-oil emulsion consisting of $440 \mathrm{mg} \mathrm{g}^{-1}$ paraffin, $110 \mathrm{mg} \mathrm{g}^{-1}$ lanolin (water-free grade) and $450 \mathrm{mg} \mathrm{g}^{-1} \mathrm{MilliQ}^{\circledR}$ water was prepared. The lanolin was molten in a water bath (about $330 \mathrm{~K}$ ) and mixed with paraffin to a homogeneous phase. Then the oil phase was mixed with water and shaken manually, until it was a stable emulsion with microsized water droplets embedded in the oil. A droplet of this emulsion was placed on a glass slide and spiked with $20 \mathrm{mg} \mathrm{mL}^{-1}$ of fungal spores, so that all droplets contained several spores (see Fig. 2), and to make the data comparable with former measurements (Pummer et al., 2012). This way ensured that if there are ice nuclei present on the spores, they cannot be missed due to underdosing. The sample prepared in this way was placed in a cryocell, which was cooled by a UEPT-330-119-045C200 Peltier stage at a cooling rate of about $2 \mathrm{~K} \mathrm{~min}^{-1}$, where it was observed with a microscope at $200 \times$ total magnification. Photos were taken with a Hengtech MDC320 microscope camera during the cooling ramp. The number of frozen droplets was counted in every picture and plotted against temperature. By summation over two to eight individual 
Table 2. A list of $T_{50}$ values for different ice nuclei in the oil immersion mode. Values of references are taken from Pummer et al. (2012). Species labeled with "N" in the TUCIM column are the food mold samples. $d$ is the longitudinal diameter of a single spore, \# the total number of counted droplets.

\begin{tabular}{|c|c|c|c|c|c|c|}
\hline Group & Species & TUCIM \# & $d[\mu \mathrm{m}]$ & $\#$ & $T_{50}[\mathrm{~K}]$ & $T_{10}[\mathrm{~K}]$ \\
\hline \multirow[t]{24}{*}{ Ascomycota } & F. avenaceum & & 7 & 301 & 264 & 268 \\
\hline & F. oxysporum & & 7 & 335 & 238 & 246 \\
\hline & $F . s p$ & 4237 & - & 64 & 237 & 242 \\
\hline & $F . s p$ & 4682 & - & 130 & 237 & 245 \\
\hline & F.sp. & 4686 & - & 81 & 238 & 244 \\
\hline & A. oryzae & & 3 & 730 & 242 & 247 \\
\hline & A. fumigatus & & 3 & 230 & 239 & 241 \\
\hline & A. niger & & 3 & 120 & 237 & 239 \\
\hline & A. niger & $\mathrm{N}$ & 3 & 501 & 239 & 245 \\
\hline & P. chrysogenum & & 3 & 365 & 236 & 243 \\
\hline & P. chrysogenum & $\mathrm{N}$ & 3 & 348 & 239 & 243 \\
\hline & P. citrinum & $\mathrm{N}$ & 3 & 894 & 237 & 241 \\
\hline & P. digitatum & & 3 & 154 & 240 & 244 \\
\hline & P. glabrum & & 3 & 462 & 237 & 247 \\
\hline & T. atroviride & 626 & 4 & 50 & 241 & 245 \\
\hline & T. atroviride & 1680 & - & 109 & 239 & 244 \\
\hline & T. atroviride & 1836 & - & 217 & 238 & 243 \\
\hline & T. atroviride & 3001 & - & 60 & 240 & 242 \\
\hline & T. longibrachiatum & 1301 & - & 126 & 241 & 244 \\
\hline & T. reesei & 917 & 3 & 711 & 237 & 247 \\
\hline & T. virens & 2550 & 4 & 208 & 237 & 244 \\
\hline & C. cladosporioides & & 6 & 1152 & 237 & 247 \\
\hline & C. herbarum & & 6 & 145 & 237 & 240 \\
\hline & E. album & & 3 & 157 & 237 & 245 \\
\hline \multirow[t]{5}{*}{ Basidiomycota } & \multicolumn{2}{|l|}{ Lentinula edodes } & 4 & 523 & 247 & 250 \\
\hline & \multicolumn{2}{|c|}{ Agaricus bisporus avellaneous } & 6 & 594 & 243 & 245 \\
\hline & \multicolumn{2}{|c|}{ Agaricus bisporus albidus } & 6 & 671 & 241 & 244 \\
\hline & \multicolumn{2}{|l|}{ Pleurotus ostreatus } & 5 & 391 & 240 & 247 \\
\hline & \multicolumn{2}{|l|}{ Psilocybe cubensis } & 9 & 282 & 238 & 243 \\
\hline \multirow[t]{3}{*}{ References } & \multirow{3}{*}{\multicolumn{2}{|c|}{$\begin{array}{l}\text { Snomax } \\
\text { birch pollen water } \\
\text { blank }\end{array}$}} & & 250 & 268 & 269 \\
\hline & & & & 457 & 254 & 257 \\
\hline & & & & 654 & 237 & 239 \\
\hline
\end{tabular}

curves for each sample, a total droplet nucleation curve was generated. The temperature with $50 \%$ of all droplets frozen $\left(T_{50}\right.$, also known as the median freezing temperature) and the temperature with $10 \%$ frozen $\left(T_{10}\right)$ were chosen to compare different samples with a numeric value. Only droplets in the range from 10 to $200 \mu \mathrm{m}$ were taken into account, because smaller droplets are difficult to assign, while larger droplets are less representative and cover much of the space in the field of view. About half of the total counted droplets were smaller than $40 \mu \mathrm{m}$, which corresponds to a droplet volume of $33.5 \mathrm{pl}$.

To test if the method itself is reliable, an extract of an IN active $F$. acuminatum culture (culture provided by Linda Hanson, Michigan State University), which was filtered through a $0.1 \mu \mathrm{m}$ filter, was measured in the cryomicroscopic setup. It showed an initial freezing temperature of $267 \mathrm{~K}$ and a steep slope, which decreases with falling tem- perature. At $243 \mathrm{~K} 73 \%$ of all droplets were frozen. The $T_{50}$ of this sample was $261 \mathrm{~K}$.

\subsection{Protein quantification assay}

The plates left from Sect. 2.1 were harvested analogously, but in water as a solvent instead of ethanol. The suspensions were then investigated with the Bradford method (Bradford, 1976) to determine the total protein content. Therefore, spore suspensions were diluted to a given concentration by measuring the light transmission. A vial of pure water (100\% transmission) was prepared, and spore suspensions were slowly added, until the transmission dropped to 66-68\%. Then $1 \mathrm{~mL}$ of the suspension was mixed with $0.5 \mathrm{~mL}$ Bradford solution, which was prepared by diluting commercially available BioRad Protein Assay Dye Reagent Concentrate to the fivefold volume. For each sample and the blank, three vials 


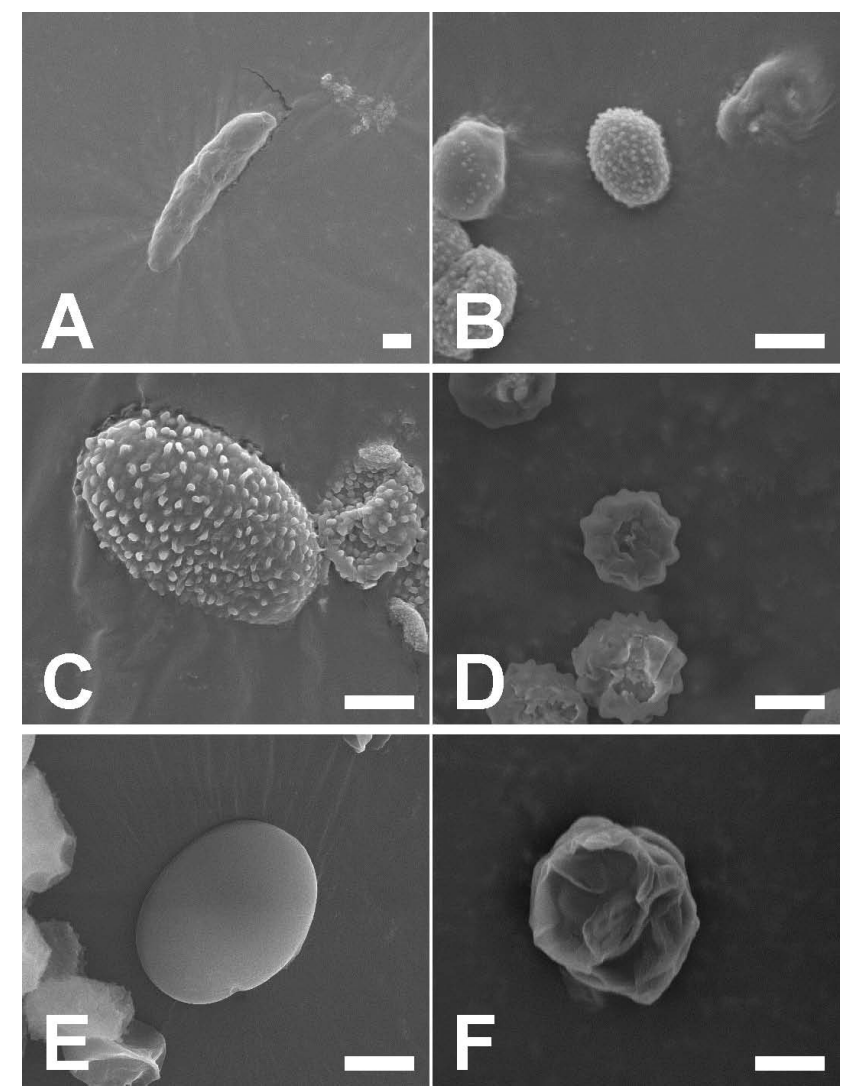

Fig. 1. Scanning electron microscopy images of some fungal spores: Fusarium avenaceum (A), Trichoderma atroviride (B), Cladosporium herbarum $(\mathbf{C})$, Aspergillus niger (D), Agaricus bisporus $(\mathbf{E})$ and Lentinula edodes $(\mathbf{F})$. The white bar represents a length of $2 \mu \mathrm{m}$ and is valid for all pictures.

were prepared and measured. We measured the absorbance at $565 \mathrm{~nm}$ to quantify the total protein content. The total protein contents are listed in Table 3.

\subsection{Ice nucleation in droplet arrays}

To confirm the data from the oil immersion method, some of the samples were further investigated with a setup where the droplets are not surrounded by oil, which might have influenced the results.

The sample carrier was in this case a sterile, 96-well polypropylene PCR tray. Aliquots of $50 \mu \mathrm{L}$ of either pure water or a suspension with a concentration of $1 \mathrm{mg} \mathrm{mL}^{-1}$ were tested. Only for birch pollen water, a concentration of $2.5 \mathrm{mg} \mathrm{mL}^{-1}$ pollen was applied, but then the pollen bulks were filtered off, which led to a material concentration of about $1 \mathrm{mg} \mathrm{mL}^{-1}$ (see Pummer et al. (2012) for further explanation). Higher dilutions than in the oil immersion setup were necessary, since the droplet volume was much bigger and therefore contained more spores at a given concentration. Droplets with $20 \mathrm{mg} \mathrm{mL}^{-1}$ spores were so loaded that they became intransparent and were therefore not applicable.

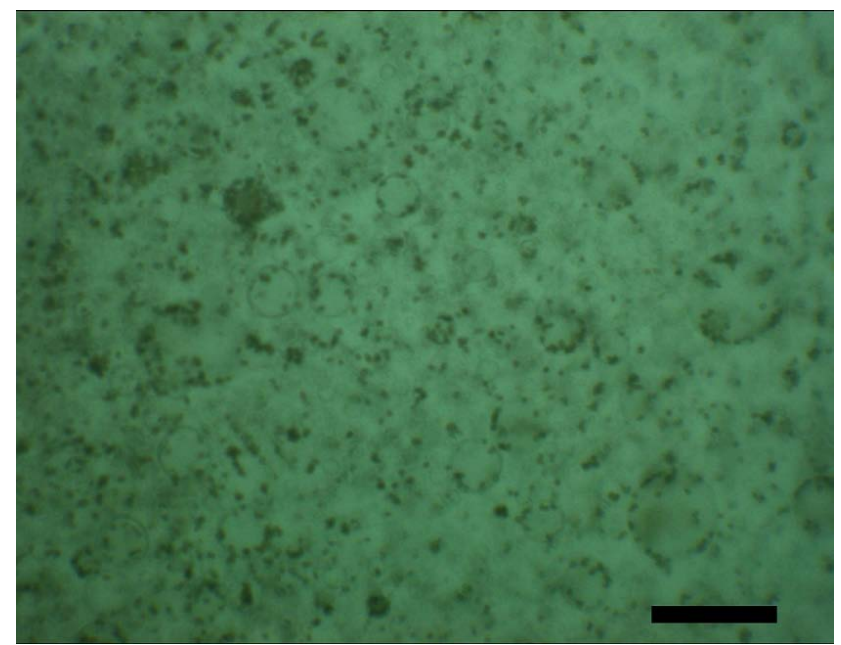

Fig. 2. A capture of an emulsion spiked with Agaricus bisporus avellaneous spores. The bar represents a length of $150 \mu \mathrm{m}$. It shows that spores are present in both the droplets and in the oil phase.

The PCR tray was then sealed with adhesive foil to prevent external contamination.

The PCR plate was cooled in a 96-well aluminium block that is connected to a Julabo Presto A30 thermostat operated with Thermal HLAO as the cooling liquid. To measure and regulate the block temperature, an additional PT100 temperature sensor was integrated within the cooling block. The cooling block, which was thermostated to $273 \mathrm{~K}$, was then cooled down in $3 \mathrm{~K}$ steps every $12 \mathrm{~min}$, which was ample time for the system to equilibrate at the demanded temperature. Via optical inspection, the aggregation state of each droplet was determined and counted. In the case of liquid droplets, the reflection of the ambient light formed a bright ring on the well floor. When a droplet froze, this reflection ring vanished, or was at least severely reduced. The fraction of frozen droplets for each sample was then plotted against temperature, the same way it was done for the oil immersion measurements. The applied samples and their $T_{50}$ are presented in Table 4 . It should be mentioned that below $258 \mathrm{~K}$ the discrimination between heterogeneous and homogeneous IN became difficult, therefore samples active at these temperatures can hardly be seen as ice nuclei.

\section{Results and discussion}

\subsection{General part}

Our measurements affirmed that fungal IN activity seems to be not very common among fungi. All but one strain of fungi tested in this study showed no or negligible IN activity. Fusarium avenaceum showed high activity in our measurements, which is close to Snomax ${ }^{\mathrm{TM}}$ activity. Lentinula edodes showed mediocre IN activity, comparable to that of average 
Table 3. A list of $T_{50}$ values and total protein concentrations $(C)$ for Ascomycota spores cultivated under different conditions. Columns marked with an asterisk show results of cultures that were exposed to freezing stress during growth. No error bars were given for $C$, because it was only $1-2 \mu \mathrm{g} \mathrm{mL}^{-1}$ with the exception of strain number 626 , where it was $4-5 \mu \mathrm{g} \mathrm{mL}-1$.

\begin{tabular}{|c|c|c|c|c|c|c|}
\hline \multirow[t]{2}{*}{ Group } & \multirow[t]{2}{*}{ Species } & \multirow[t]{2}{*}{ TUCIM \# } & \multicolumn{2}{|c|}{$T_{50}[\mathrm{~K}]$} & \multicolumn{2}{|c|}{$C\left[\mu \mathrm{g} \mathrm{mL}^{-1}\right]$} \\
\hline & & & & $*$ & & $*$ \\
\hline \multirow[t]{7}{*}{ Ascomycota } & F.sp. & 4237 & 237 & 238 & 173 & 144 \\
\hline & F.sp. & 4682 & 237 & 237 & 153 & 124 \\
\hline & F.sp. & 4686 & 238 & 237 & 145 & 113 \\
\hline & T. atroviride & 626 & 241 & 237 & 99 & 96 \\
\hline & T. atroviride & 1680 & 238 & 238 & 102 & 99 \\
\hline & T. atroviride & 3001 & 240 & 239 & 79 & 93 \\
\hline & T. longibrachiatum & 1301 & 241 & 239 & 77 & 110 \\
\hline
\end{tabular}

Table 4. A list of $T_{50}$ values for different ice nuclei in the droplet array mode. Species labeled with "N" in the TUCIM column are the naturally grown food mold samples. \# is the total number of counted droplets.

\begin{tabular}{llrrrr}
\hline Group & Species & TUCIM \# & $\#$ & $T_{50}[\mathrm{~K}]$ & $T_{10}[\mathrm{~K}]$ \\
\hline \multirow{2}{*}{ Ascomycota } & F. oxysporum & & 24 & 256 & 260 \\
& A. niger & & 32 & 255 & 261 \\
& A. niger & $\mathrm{N}$ & 16 & 254 & 257 \\
& P. chrysogenum & $\mathrm{N}$ & 16 & 256 & 258 \\
& P. citrinum & $\mathrm{N}$ & 32 & 253 & 258 \\
& T. atroviride & 1836 & 40 & 256 & 260 \\
& T. reesei & 917 & 24 & 257 & 258 \\
& T. virens & 2550 & 32 & 254 & 257 \\
\hline \multirow{2}{*}{ References } & Snomax & & 40 & 271 & 271 \\
& birch pollen water & & 56 & 261 & 269 \\
& blank & & 192 & 252 & 258 \\
\hline
\end{tabular}

pollen IN and below that of the mineral dust kaolinite and ATD (Pummer et al., 2012). However, as it was one individual sample that was measured in this study, it is questionable if the Lentinula edodes species is generally a better ice nucleus than most other species. All other fungal spores can be considered IN-inactive, since an increase in nucleation temperature by some Kelvin can be caused by many different reasons and is of no atmospheric relevance. Nevertheless, the huge potential of unstudied fungal species, as well as the fact that new IN-active species can still be found (Huffman et al., 2013; Morris et al., 2013; Haga et al., 2013), suggests that further investigations into fungal IN activity are necessary.

We applied spore concentrations of $20 \mathrm{mg} \mathrm{mL}^{-1}$ in our oil immersion study. In our previous study (Pummer et al., 2012) we had pollen concentrations of $50 \mathrm{mg} \mathrm{mL}^{-1}$. As average fungal spore diameters are about a tenth of pollen diameters, the volume ratio is about a factor of 1000 . Assuming a similar density of all cellular samples, one would expect that a spore concentration of $0.05 \mathrm{mg} \mathrm{mL}^{-1}$ would be comparable. However, due to the high hydrophobia of fungal spores, many of them were lost in the oil phase of the emulsion, so far higher concentrations were necessary in our experiment.
Furthermore, since most fungal spores did not show IN activity at all, an overdosing is of less concern than an underdosing. In the second case, the IN inactivity could be the result of low concentrations, while IN inactivity in the first case is only explicable by the absence of IN on the fungal spores.

\subsection{Problems}

The basic problem of fungal IN measurements is the fact that the same species can show different behaviour in different studies, as they can lose their IN activity after in vitro maintenance as a result of changes in gene regulation (Tsumuki et al., 1995), which makes comparability with other studies difficult. For example, we could reproduce the loss of IN activity of the Fusarium avenaceum culture within time. Tsumuki et al. (1995) determined the loss of IN activity in the second (F. moniliforme) to fifth ( $F$. avenaceum) subcultures when growing them in liquid media. Our $F$. avenaceum cultures, which were grown on agar plates, stayed active for more than ten generations. Transcription regulation, like the shutting on and off of a gene, is an important, but very complex tool of evolution for generating biological diversity (Levine and Tjian, 2003). Furthermore, the setup parameters themselves, 
like the ice nuclei content per droplet, have an impact on nucleation temperature. Therefore the results of a study have to be compared with well-known reference points, like the median freezing temperature of Snomax ${ }^{\mathrm{TM}}$ at a given concentration, or sample-free water.

Jayaweera and Flanagan (1982) found appreciable IN activity in P. digitatum $(263 \mathrm{~K})$ and $C$. herbarum $(258 \mathrm{~K})$ in comparison to pure water $(\sim 248 \mathrm{~K})$. This stands in contrast to our oil immersion data, where both species showed no IN activity. Several explanations can be brought up: (i) as already found by Tsumuki et al. (1995), the cultivation conditions and the fungal strain have an impact on IN activity. While our two samples were gathered from a fungal database, Jayaweera and Flanagan collected their samples in the Arctic atmosphere, where conditions are harsh. (ii) In the setup by Jayaweera and Flanagan (1982), the material amount per droplet was higher due to the large droplet volume. Therefore, the probability of finding an active site in a droplet is high, even if the sample has little IN activity. The comparison of the pure water data between the two studies shows that the freezing temperatures are shifted towards higher temperatures in the former study ( $248 \mathrm{~K}$ vs. $237 \mathrm{~K}$ ). (iii) It might be that the ice nuclei of these species are far more hydrophobic than those of bacteria, pollen, Fusarium and mineral dust particles. In this case, they would move into the oil phase and not be in contact with the water droplets any more, which is necessary to initiate ice formation. Our data from the droplet array setup, however, confirm the data from the oil immersion device. Furthermore, the measurements with F. acuminatum and Snomax ${ }^{\mathrm{TM}}$ show that strong ice nuclei should definitely initiate freezing in the oil immersion. It should be mentioned that Snomax ${ }^{\mathrm{TM}}$ also contains a lot of IN-inactive material (e.g. the growth medium), and that among the bacterial cells only a fraction carries the IN-active sites. Although one can assume that a part of the ice nuclei is lost in the oil phase, there was enough activity left to discriminate efficient ice nuclei from IN-inactive samples, which show merely homogeneous nucleation. Only at very low concentrations is the IN activity expected to be completely lost in the oil phase; however, these concentrations would not be significant for the atmosphere, where they would compete with other ice nuclei that are superior concerning activity and abundance.

\subsection{IN activity of fungal spores does not depend on protein concentration}

The Bradford assay demonstrated the impact of freezing stress during sporulation on the total protein content of spores. While there was a reduction in protein content of Fusarium spores as a response to stress, the T. atroviride strains were not affected by it. The Antarctic T. longibrachiatum species even increased its protein content in response to cryo-stress. It might be that this certain strain is adapted to dwell in cold environments. As a whole, no correlation be- tween total protein content and IN activity was visible, since none of the investigated species showed any IN activity.

It can be seen in the SEM captures (Fig. 1) that despite the enormous differences in surface topology, the differences in IN activity are negligible. This way we can exclude that ice nucleation can be caused by topology alone.

\section{Conclusions}

According to our results, fungal ice nucleation seems to be an exclusive property restricted to relatively few species. As stated in Sect. 3.2, the found results have to be taken with care as a general statement. Therefore, further investigations with a broad spectrum of species, as well as studies with different methods, are necessary to confirm this hypothesis. Nevertheless, this study showed that the ice nucleus present in the $F$. avenaceum strain is unique among our samples. This makes sense if we consider the assumed reasons for the existence of biological ice nuclei: the purpose of a fungal IN expression could be either a cryoprotective mechanism like in lichen (Kieft and Ahmadjian, 1989), or a tool for causing frost injury to plants, thus making nutrients more available for phytopathogenic molds like the Fusarium species (Richard et al., 1996). The same process has already been observed for IN-active bacteria (Lindow, 1983). As Fusarium and lichen species typically grow under cold, harsh outdoor conditions, adaptation by ice nuclei expression seems a sensible strategy. On the other hand, the typical molds affecting food storages, like Aspergillus and Penicillium, are exposed to far more convenient life conditions, what could explain IN inactivity.

Although it looks as if the majority of fungal strains and species that exist reveal no or only very poor IN activity, findings of new IN-active fungi do occur (Huffman et al., 2013; Morris et al., 2013; Haga et al., 2013). The broad spectrum of uninvestigated and unknown species - according to current estimations, there might be more than a million fungal species on the planet - harbours a vast potential for IN activity, even if only a tiny fraction of them can express ice nuclei. Therefore further investigations of fungi will be necessary in the future. Morris et al. (2013) followed the approach of focussing on species with a lifecycle in which ice formation might be advantageous for the fungus. This approach is consistent with what is known about the IN-active bacteria, lichen and Fusarium species.

Iannone et al. (2011) suggested that the poor IN ability of Cladosporium spores may be attributed to the surface which is coated with hydrophobins. These are small (about $10 \mathrm{kDa}$ ) cysteine-rich amphiphilic proteins unique to filamentous fungi (Wösten et al., 1995; Frischmann et al., 2013). As they are much smaller than the known IN proteins, their activity principally has to be negligible, since an IN-active center is the more effective the more active surface it facilitates (Warren and Wolber, 1991). The four Trichoderma 
species investigated in this study (T. virens, T. atroviride, $T$. reesei and T. longibrachiatum) have the profound expansion of hydrophobin genes in their genomes compared to the other species, including members of the Fusarium genus (Kubicek et al., 2011). Moreover, the transcriptomic study on genes involved in conidiation in these fungi confirmed the high level of hydrophobins expression associated with the conidiation (Metz et al., 2011). As none of the four species in this study showed any considerable IN activity in our study, hydrophobins might be correlated with poor IN activity.

As $F$. avenaceum has an outstanding IN activity in comparison to other species investigated in this study, it is most probable that fungal IN activity is caused by only a few specific proteins or other macromolecular compounds. Bacterial IN can be derived from one protein that only slightly varies among IN-positive species (Lindow, 1995). Furthermore, this IN protein is only expressed by a small fraction of known bacterial strains. As the situation seems to be analogous in fungi, their IN activity could be correlated with one defined sequence on the genome. Unfortunately, the genome of $F$. avenaceum is not fully sequenced, so for further progress on this topic a full sequencing is of crucial importance.

The occurrence of freezing events had no impact on the fungal IN activity. This could mean either that other parameters are more important for expressing IN (e.g. starvation), or that a combination of factors is necessary. Furthermore, one might increase IN activity by overexpression of suitable proteins in a fungal isolate.

Acknowledgements. We are grateful for financial support from Vienna University of Technology within Innovative Project "The impact of biological structures on ice nucleation", from the Austrian Science Fund (projects P23027, P26040), from the Max Planck Society, the INUIT (Ice Nuclei research UnIT) and the German Research Foundation (project PO1013/5-1). We also thank the OMV for funding the light microscope. Furthermore we acknowledge R. Rosner for technical support and B. Aquino for laboratory assistance.

Edited by: G. Wohlfahrt

\section{References}

Ariya, P. A., Sun, J., Eltouny, N. A., Hudson, E. D., Hayes, C. T., and Kos, G.: Physical and chemical characterization of bioaerosols - Implications for nucleation processes, Int. Rev. Phys. Chem., 28, 1-32, 2009.

Bauer, H., Kasper-Giebl, A., Löflund, M., Giebl, H., Hitzenberger, R., Zibuschka, F., and Puxbaum, H.: The contribution of bacteria and fungal spores to the organic carbon content of cloud water, precipitation and aerosols, Atmos. Res., 64, 109-119, 2002.

Bradford, M. M.: Rapid and sensitive method for the quantitation of microgram quantities of protein utilizing the principle of proteindye binding, Anal. Biochem., 72, 248-254, doi:10.1016/00032697(76)90527-3, 1976.
Frischmann, A., Neudl, S., Gaderer, R., Bonazza, K., Zach, S., Gruber, S., Spadiut, O., Friedbacher, G., Grothe, H., and SeidlSeiboth, V.: Self-assembly at air/water interfaces and carbohydrate binding properties of the small secreted protein EPL1 from the fungus Trichoderma atroviride, J. Biol. Chem., 288, 42784287, 2013.

Fröhlich-Nowoisky, J., Pickersgill, D. A., Després, V. R., and Pöschl, U.: High diversity of fungi in air particulate matter, P. Natl. Acad. Sci., 106, 12814-12819, 2009.

Gurian-Sherman, D. and Lindow, S. E.: Bacterial ice nucelation: significance and molecular basis, FASEB J., 7, 1338-1343, 1993.

Haga, D. I., Iannone, R., Wheeler, M. J., Mason, R., Polishchuk, E. A., Fetch, T. Jr., van der Kamp, B. J., McKendry, I. G., and Bertram, A. K.: Ice nucleation properties of rust and bunt fungal spores and their transport to high altitudes, where they can cause heterogeneous freezing, J. Geophys. Res., 118, 72607272, doi:10.1002/jgrd.50556, 2013.

Hasegawa, Y., Ishihara, Y., and Tokuyama, T.: Characteristics of Ice-nucelation Activity in Fusarium avenaceum IFO 7158, Biosci. Biotech. Bioch., 58, 2273-2274, 1994.

Hoose, C., Kristjansson, J. E., and Burrows, S. M.: How important is biological ice nucleation in clouds on a global scale? Environ. Res. Lett., 5, 024009, doi:10.1088/1748-9326/5/2/024009, 2010.

Huffman, J. A., Prenni, A. J., DeMott, P. J., Pöhlker, C., Mason, R. H., Robinson, N. H., Fröhlich-Nowoisky, J., Tobo, Y., Després, V. R., Garcia, E., Gochis, D. J., Harris, E., Müller-Germann, I., Ruzene, C., Schmer, B., Sinha, B., Day, D. A., Andreae, M. O., Jimenez, J. L., Gallagher, M., Kreidenweis, S. M., Bertram, A. K., and Pöschl, U.: High concentrations of biological aerosol particles and ice nuclei during and after rain, Atmos. Chem. Phys., 13, 6151-6164, doi:10.5194/acp-13-6151-2013, 2013.

Iannone, R., Chernoff, D. I., Pringle, A., Martin, S. T., and Bertram, A. K.: The ice nucleation ability of one of the most abundant types of fungal spores found in the atmosphere, Atmos. Chem. Phys., 11, 1191-1201, doi:10.5194/acp-11-1191-2011, 2011.

Imshenetsky, A. A., Lysenko, S. V., and Kazakov, G. A.: Upper boundary of the biosphere, Appl. Environ. Microb., 35, 1-5, 1987.

Jayaweera, K. and Flanagan, P.: Investigation on biogenic ice nuclei in the Arctic atmosphere, Geophys. Res. Lett., 9, 94-97, 1982.

Kawahara, H.: The structures and function of ice crystal-controlling proteins from bacteria, J. Biosci. Bioeng., 94, 492-496, 2002.

Kieft, T. L.: Ice nucleation activity in lichens, Appl. Environ. Microb., 54, 1678-1681, 1988.

Kieft, T. L. and Ahmadjian, V.: Biological ice nucleation in lichen mycobionts and photobionts, Lichenologist, 21, 355-362, 1989.

Kieft, T. L. and Ruscetti, T.: Characterization of biological ice nuclei from a lichen, J. Bacteriol., 172, 3519-3523, 1990.

Kubicek, C. P., Herrera-Estrella, A., Seidl-Seiboth, V., Martinez, D. A., Druzhinina, I.S., Thon, M., Zeilinger, S., Casas-Flores, S., Horwitz, B. A., Mukherjee, P. K., Mukherjee, M., Kredics, L., Alcaraz, L. D., Aerts, A., Antal, Z., Atanasova, L., CervantesBadillo, M. G., Challacombe, J., Chertkov, O., McCluskey, K., Coulpier, F., Deshpande, N., von Döhren, H., Ebbole, D. J., Esquivel-Naranjo, E. U., Fekete, E., Flipphi, M., Glaser, F., Gómez-Rodríguez, E. Y., Gruber, S., Han, C., Henrissat, B., Hermosa, R., Hernández-Oñate, M., Karaffa, L., Kosti, I., Le Crom, S., Lindquist, E., Lucas, S., Lübeck, M., Lübeck, P. S., Margeot, A., Metz, B., Misra, M., Nevalainen, H., Omann, M., Packer, N., 
Perrone, G., Uresti-Rivera, E. E., Salamov, A., Schmoll, M., Seiboth, B., Shapiro, H., Sukno, S., Tamayo-Ramos, J. A., Tisch, D., Wiest, A., Wilkinson, H. H., Zhang, M., Coutinho, P. M., Kenerley, C. M., Monte, E., Baker, S. E., and Grigoriev, I. V.: Comparative genome sequence analysis underscores mycoparasitism as the ancestral lifestyle of Trichoderma, Genome Biol., 12, R40, doi:10.1186/gb-2011-12-4-r40, 2011.

Levine, M. and Tjian, R.: Transcription regulation and animal diversity, Nature, 424, 147-151, 2003.

Lindow, S. E.: The role of bacterial ice nucleation in frost injury to plants, Annu. Rev. Phytopathol., 21, 363-384, 1983.

Lindow, S. E.: Membrane fluidity as a factor in production and stability of bacterial ice nuclei active at high subfreezing temperatures, Cryobiology, 32, 247-258, 1995.

Metz, B., Seidl-Seiboth, V., Haarmann, T., Kopchinskiy, A., Lorenz, P., Seiboth, B., and Kubicek, C. P.: Expression of biomassdegrading enzymes is a major event during conidium development in Trichoderma reesei, Eukaryot. Cell, 10, 1527-1535, 2011.

Morris C. E., Georgakopoulos, D. G., and Sands D. C.: Ice nucleation active bacteria and their potential role in precipitation, $\mathrm{J}$. Phys. IV, 121, 87-103, 2004.

Morris, C. E., Sands, D. C., Glaux, C., Samsatly, J., Asaad, S., Moukahel, A. R., Gonçalves, F. L. T., and Bigg, E. K.: Urediospores of rust fungi are ice nucleation active at $>-10^{\circ} \mathrm{C}$ and harbor ice nucleation active bacteria, Atmos. Chem. Phys., 13, 4223-4233, doi:10.5194/acp-13-4223-2013, 2013.

Nirenberg, H. I.: Untersuchungen über die morphologische und biologische Differenzierung in der Fusarium-Section Liseola, Mitt. Biol. Bundesanst. Land- u. Forstwirtsch. Berlin-Dahlem, 169, 1$117,1976$.

Pashley, C. H., Fairs, A., Free, R. C., and Wardlaw, A. J.: DNA analysis of outdoor air reveals a high degree of fungal diversity, temporal variability, and genera not seen by spore morphology, Fungal Biol., 116, 214-224, doi:10.1016/j.funbio.2011.11.004, 2012.

Pathre, S. V. and Mirocha, C. J.: Analysis of Deoxynivalenol from Cultures of Fusarium Species, Appl. Environ. Microb., 35, 992 994, 1978.
Pearce, D. A., Bridge, P. D., Hughes, K. A., Sattler, B., Psenner, R., and Russell, N. J.: Microorganisms in the atmosphere over Antarctica, FEMS Microbiol. Ecol., 69, 143-157, 2009.

Pouleur, S., Richard, C., Martin. J. G., and Antoun, H.: Ice nucleation activity in Fusarium acuminatum and Fusarium avenaceum, Appl. Environ. Microb., 58, 2960-2964, 1992.

Pummer, B. G., Bauer, H., Bernardi, J., Bleicher, S., and Grothe, H.: Suspendable macromolecules are responsible for ice nucleation activity of birch and conifer pollen, Atmos. Chem. Phys., 12, 2541-2550, doi:10.5194/acp-12-2541-2012, 2012.

Richard, C., Martin, J.-G., and Pouleur, S.: Ice nucleation activity identified in some phytopathogenic Fusarium species, Phytoprotection, 77, 83-92, 1996.

Schüller, E.: Vergleichende mikroskopische und molekularbiologische Untersuchungen von Pilzsporen in Feinstaubproben, MSc Thesis, BOKU Vienna, 2008.

Sesartic, A., Lohmann, U., and Storelvmo, T.: Modelling the impact of fungal spore ice nuclei on clouds and precipitation, Environ. Res. Lett., 8, 014029, doi:10.1088/1748-9326/8/1/014029, 2013.

Tsumuki, H. and Konno, H.: Ice nuclei produced by Fusarium sp. Isolated from the gut of the rice stem borer Chilo suppressalis WALKER (Lepidoptera: Pyralidae), Biosci. Biotech. Bioch., 58, 578-579, 1994.

Tsumuki, H., Yanai, H., and Aoki, T.: Identification of icenucleating active fungus isolated from the gut of the rice stem borer, Chilo suppressalis Walker (Lepidoptera: Pyralidae) and a search for ice-nucleating active Fusarium species, Ann. Phytopathol. Soc. Jpn., 61, 334-339, 1995.

Vali, G., Christensen, M. Fresh, R. W., Galyan, E. L., Maki, L. R., and Schnell, R. C.: Biogenic Ice Nuclei. Part II: Bacterial Sources, J. Atmos. Sci., 33, 1565-1570, 1976.

Warren, G. and Wolber, P.: Molecular aspects of microbial ice nucleation, Mol. Microbiol., 5, 239-243, 1991.

Wösten, H. A. B., Ruardy, T. G., van der Mei, H. C., Busscher, H. J., and Wessels, J. G. H.: Interfacialself-assembly of a Schizophyllum commune hydrophobin into an insoluble amphipatic protein membrane depends on surface hydrophobicity, Colloid. Surface. B, 5, 189-195, 1995. 